\title{
Mindre luftforurensning gir bedre lungefunksjon
}

\author{
Renere luft er assosiert med bedre lungefunksjon hos store barn. \\ Det viser en studie fra USA.
}

Tidligere studier har vist at høye nivåer av luftforurensning er assosiert med nedsatt lungefunksjon hos barn. I California har målrettede tiltak bidratt til å redusere forurensningen i de senere år, men det er uklart om dette har gitt bedre barnehelse.

I en nylig publisert studie ble lungefunksjonen i tre kohorter med til sammen 2120 barn (gjennomsnittsalder 11 år ved inklu- sjon) målt årlig i periodene 1994-98, 1997-2001 og 2007-11 (1). Forbedret luftkvalitet, blant annet med synkende nivåer av nitrogendioksid, var signifikant assosiert med bedre lungefunksjon, målt med forsert ekspiratorisk volum etter ett sekund $\left(\mathrm{FEV}_{1}\right)$ og forsert vitalkapasitet (FVK). Effektene var til stede hos både gutter og jenter både med og uten astma. Andelen barn med FEV 1

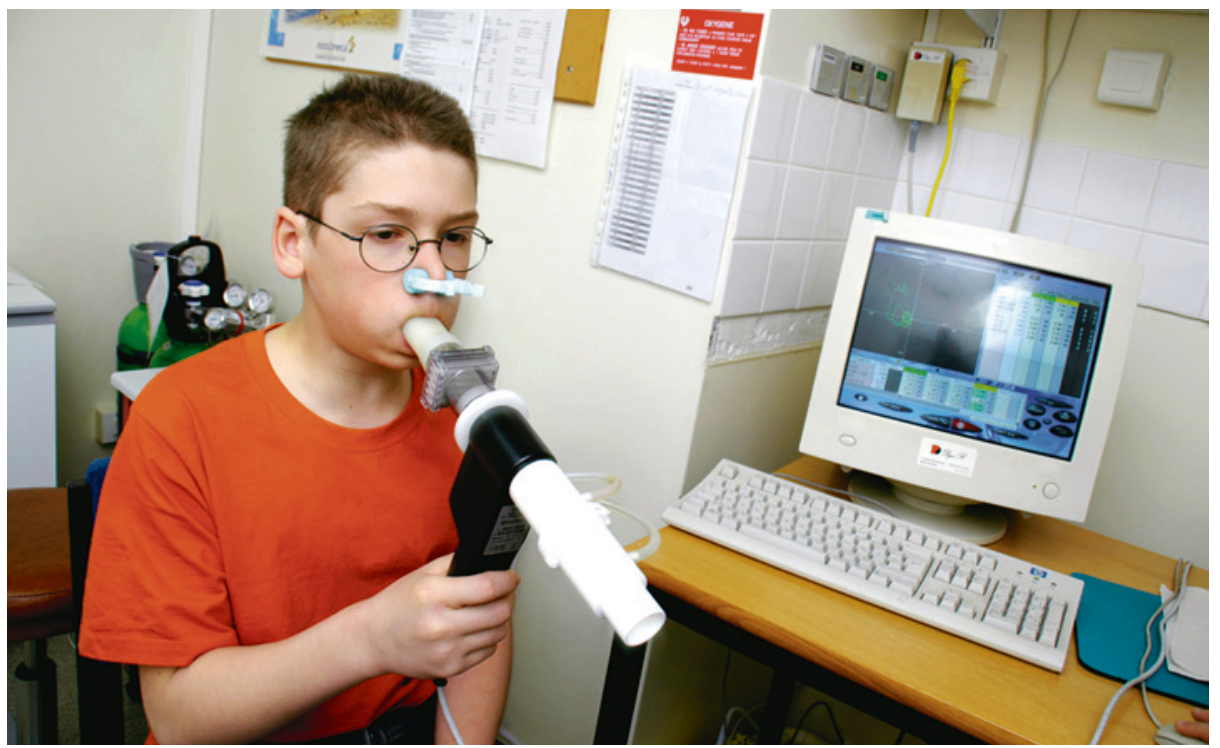

Illustrasjonsfoto: Science Photo Library

$<80 \%$ av forventet verdi ved 15 års alder sank signifikant fra 7,9\% til 6,3\% til 3,6\% i løpet av de tre periodene.

- Bedre lungefunksjon $\mathrm{i}$ tenårene kan gi bedre helse $\mathrm{i}$ voksen alder, sier Bente Oftedal, som er seniorforsker ved Folkehelseinstituttet. - Forfatterne av denne studien sier at redusert lungefunksjon hos barn kan ha sammenheng med økt risiko for astma. Studier har vist at bedre lungefunksjon i voksen alder kan bidra til å redusere risikoen for hjerte- og karsykdommer og prematur død, sier hun.

- Den største svakheten ved studien er at eksponeringen for luftforurensning ble beregnet ved hjelp av målestasjoner innenfor store områder, slik at alle tenåringene som var bosatt i samme område, ble tillagt samme eksponering. Denne grove beregningen av eksponering gjør at funnene er usikre, fortsetter hun.

- Luftforurensningsnivåene i urbane strøk i Norge har ikke avtatt på samme måte som i California, nivåene av nitrogendioksid i norske byer har faktisk økt noe de siste tiårene. Likevel er nivåene fortsatt lavere enn i studien fra California. Derfor er det usikkert om den påviste assosiasjonen også gjelder for barn i Norge, sier Oftedal.

\section{Lise Mørkved Helsingen \\ Tidsskriftet}

\section{Litteratur}

1. Gauderman WJ, Urman R, Avol E et al. Association of improved air quality with lung development in children. N Engl J Med 2015; 372: 905-13.

\section{Mindre muskelsvinn etter trening ved akutt lungesvikt}

\section{Studier hos mus bidrar til å forklare mekanismen bak den gunstige effekten av tidlig mobilisering ved akutt lungesviktsyndrom.}

Akutt lungesviktsyndrom (acute respiratory distress syndrome, ARDS) er en inflammatorisk tilstand utløst av alvorlig infeksjon, traume og/eller sirkulasjonssvikt og er forbundet med høy dødelighet. Tidlig mobilisering synes å ha gunstig effekt, men kunnskapen om hvilke mekanismer som er involvert er mangelfull.

I en nylig publisert studie ble mus med akutt lungeskade, indusert av endotoksiner, 24 timer senere trent i tredemølle i to dager (1).
Moderat trening i korte perioder bidro til mindre muskelsvinn, men det gjorde ikke høyintensitetstrening $\mathrm{i}$ lengre perioder. Moderat trening reduserte produksjonen av granulocyttkolonistimulerende faktor (G-CSF) og granulocyttinfiltrasjonen i lungene. Det var også lavere G-CFS-nivåer hos pasienter med akutt lungesviktsyndrom som ble mobilisert tidlig enn hos pasienter som ikke ble det.

- Nye studier har vist at tidlig mobilisering av pasienter med akutt lungesviktsyndrom bidrar til mindre muskelsvinn og raskere gjenopptakelse av spontanventilasjon, sier professor Lars J. Bjertnæs ved Institutt for klinisk medisin ved Universitetet i Troms $\varnothing-$ Norges arktiske universitet. - I denne studien svekket musenes trening muskelringfinger 1 (MuRF1)-mediert atrofi av ekstremitets- og respirasjonsmuskulaturen og forbedret regenereringen av muskelstyrke. Blokkering av G-CSF-reseptorene reduserte granulocyttinfiltrasjon i lungene, men hemmet ikke muskelforandringene hos musene. Flere studier trengs for å forklare mekanismene bak denne positive virkningen av fysisk trening og for å utvikle adekvat behandling, sier Bjertnæs.

\section{Trine B. Haugen}

Tidsskriftet

\section{Litteratur}

1. Files DC, Liu C, Pereyra A et al. Therapeutic exercise attenuates neutrophilic lung injury and skeletal muscle wasting. Sci Transl Med 2015; 7: 278ra32. 